\title{
The Impact of Industrial Supplier-Manufacturer Relationship on Strategic Outsourcing Success
}

\author{
Mohamad Ghozali Hassan, ${ }^{, *}$ Mohammed Rizal Razali, asmat Nizam Abdul,a \\ "School of Technology Management and Logistics, College of Business, Universiti Utara Malaysia,06010 Sintok, Kedah \\ *Corresponding author: ghozali@uum.edu.my
}

Article history

Received: 27 July 2014

Received in revised form:

10 December 2014

Accepted: 1 February 2015

Graphical abstract

\begin{abstract}
Outsourcing is generally recognized as a strategy for producing cost savings; however, by simply following a traditional cost-focused approach, industries may be missing opportunities to gain further competitive advantage. Similarly, poor outsouncing performance of manufacturing industry could be improved through relational-oriented exchanges and its antecedents. Researches that examine the link among relational-oriented exchanges and their antecedents; and outsourcing performances in the manufacturing industry is still in its early development stage. Owing to high competition and risks in a manufacturing environment, the present study aims at investigating the link between relational-oriented exchanges, the antecedent of relational-oriented exchanges and outsourcing performances. Data was collected from 224 electrical and electronic industries in Malaysia via a postal survey and analyzed by using statistical package for social science (SPSS) version 19. The result of the findings of the investigation revealed that dependence and communication behavior are significantly related to relationaloriented exchanges while trust is insignificant. And also, relational-oriented exchange is directly significant to outsourcing performances.
\end{abstract}

Keywords: Relational-oriented exchange, antecedent, outsourcing performance, dependence, communication behavior, trust.

C 2015 Penerbit UTM Press. All rights reserved

\subsection{INTRODUCTION}

Outsourcing, or what is commonly known as subcontracting, employs resources out of the organization. The purpose is to carry out jobs which are generally performed within the organization on its own. In this current competitive world, successful outsourcing is a powerful tool. Organizations can materialize as to create value and expand the competitive advantage ahead of competitors. Organizations can concentrate on their main competencies and then depend on outsourcing partners for complementary operations. The developing of strategic relationship can normally produce synergy between organizations. Synergism that is capable to be directed to immediate and permanent advantages with some of them measured in financial terms while others in non-financial terms.

Malaysian American Electronic Industry reported that local electrical and electronic industries faced gaps in their outsourcing practices. It was not able to raise local sourcing by 50 per cent being inflexible to customer needs, despite substantial investment [1]. These arguments show that the electrical and electronic industries' outsourcing performances in Malaysia need improvement. Hence, this study will examine the factors that contribute to electrical and electronic industries outsourcing success in Malaysia. There are two main issues concerning the enhancement of outsourcing success.
First, for the improvement of outsourcing performance, relationaloriented exchange in terms of structural and process dimensions would play a major role $[2,3]$. The relational-oriented exchange is considered as a durable relation of the two parties controlled by the relational norms and ethical principles [4]. For the manufacturing industry, these relationships are separated by structure and process elements of any long-term relationship between supplier and manufacturer [5]. The structural dimension refers to the close relationship and the process reflects a joint action of activities between supplier and manufacturer. In supplier-manufacturer exchanges, the performance hinges largely on relational exchanges providing intense cooperation, joint planning, and mutual adopting of each other's needs [6].

Second, the outsourcing performance is also closely related to the antecedents of relational-oriented exchanges [7]. Antecedents of relational-oriented exchanges are the elements determining the relational orientation of an exchange [7]. In the manufacturing industry, those variables are categorized as economic factor, social factor, and communication behavior to motivate, or drive the development of supplier-manufacturer relationship quality [8]. Dependence on the economy is the determinant of governance type [9] while trust is the key social variable that explains inter-firm cooperation and long-term relationships [10]. [ palyze economic and social factors affecting the behavio and result of inter-firm relationsh [11]suggest that communication behavior is the antecedent relationship formation to maintain competitive advantage. 
Therefore, relational orientation of an exchange has its own factors to represent its quality, indicating that several variables influence the degree of relationship quality, and that the degree of relationship quality is related to the outsourcing success.

Empirical studies have shown the relationship between relational-oriented exchanges or durable relationships and performances, especially on the non-financial measures $[13,14]$. Hence, improvement in outsourcing performances is expected to be explained by relational-oriented exchanges and factors as antecedents of relational-oriented exchanges. However, the nature of the relationship between these elements has not been fully understood [15]. Furthermore, in manufacturing industry, the outsourcing performance is mainly measured by financial indicators [16]. The linkage among relational orientation of an exchange, the antecedent of the relational-oriented exchange, and the balanced performance measurement is still ambiguous. Hence, this study aims at investigating the link between relationaloriented exchanges, the antecedent of relational-oriented exchanges and the outsourcing performance.

\subsection{LITERATURE REVIEW}

\subsection{Antecedents of Relational-Oriented Exchange}

In his attempt to study the variables determining the relational orientation of an exchange, [7] conducted an investigation of six major motivations, or the reasons behind the development of inter-organizational relationships. He claims that an interorganizational relation is developed because:

1. A law or regulation stipulates that a firm purchases particular goods and services which falls under necessity;

2. The firm may improve its reputation, which falls under the purview of legitimacy;

3. Firms are desirous of exercising power or controlling another organization or the other organization's resources which falls under the purview of asymmetry;

4. Firms are desirous of managing uncertainty in the environment which falls under stability;

5. Firms aim to pursue goals or interests under reciprocity; or

6. A firm may acquire lower costs and higher benefits under the purview of efficiency.

Although the above discussed determinants may be individual causes of relationship formation in itself, the decision to initiate a relationship with another organization has its basis on many alternatives. Table 1 shows the antecedents of relational-oriented exchange dimension.

Table 1 Antecedents of Relational-oriented Exchange Dimension

\begin{tabular}{|c|c|c|}
\hline $\begin{array}{l}\text { Antecedents of } \\
\text { Supplier- } \\
\text { Manufacturer } \\
\text { Relationship } \\
\text { Dimensions }\end{array}$ & Definition & Literature \\
\hline Dependence & $\begin{array}{l}\text { Dependence is referred to as the } \\
\text { firm's requirement for } \\
\text { relationship maintenance to fulfil } \\
\text { the goals. }\end{array}$ & {$[9,17]$} \\
\hline Trust & $\begin{array}{l}\text { The inclination to depend on an } \\
\text { exchange partner in whose } \\
\text { honesty and benevolence is } \\
\text { acknowledged. }\end{array}$ & {$[10]$} \\
\hline
\end{tabular}

\begin{tabular}{|c|c|c|}
\hline $\begin{array}{l}\text { Information } \\
\text { Quality }\end{array}$ & $\begin{array}{l}\text { Communication quality is a key } \\
\text { aspect of information } \\
\text { transmission with the inclusion of } \\
\text { factors such as the accuracy, } \\
\text { timeliness, adequacy, and } \\
\text { credibility of information } \\
\text { exchanged. }\end{array}$ & {$[18,19,20,21]$} \\
\hline $\begin{array}{l}\text { Information } \\
\text { Participation }\end{array}$ & $\begin{array}{l}\text { Information participation is } \\
\text { referred to as the level to which } \\
\text { the relationship partners engage } \\
\text { in planning and goal setting } \\
\text { together. Through the } \\
\text { participation, relationship } \\
\text { members internalize goals for the } \\
\text { organizational performance and } \\
\text { are motivated to achieve those } \\
\text { mutual goals by working together } \\
\text { with the suppliers. }\end{array}$ & {$[11,22]$} \\
\hline $\begin{array}{l}\text { Information } \\
\text { Sharing }\end{array}$ & $\begin{array}{l}\text { Information sharing is defined as } \\
\text { the level to which critical, often } \\
\text { proprietary, information is } \\
\text { communicated to one's partner. } \\
\text { Close-knit ties often lead to } \\
\text { significant and frequent } \\
\text { information exchanges between } \\
\text { high performing partners. }\end{array}$ & [19] \\
\hline
\end{tabular}

Following [5], this research states that close and relationaloriented exchanges have their basis on the interaction of efficiency, stability and reciprocity motivations. In order to improve efficiency and obtain stability, an organization may try to cement a stable relationship with another. In addition, if the organization expects that higher internal efficiency will result from the relationship, there will be an increase in its desire to carry out mutually beneficial goals and interests.

\subsection{Dependence and Relational-Oriented Exchange}

Companies that cooperate to reach mutual goals are convinced of their dependence on each other; a rationale that arises from the exchange paradigm [e.g 25]. Interdependence stems from the relation wherein the supplier and manufacturer expect mutual benefits from their interaction [26] and wherein any loss are offset but expected gains [27]. Both parties acknowledge the benefits of interdependence in promoting efficiency and stability motivations, that are greater than what the entities alone could accomplish. Efficiency and stability motivations present the hope of outcome improvement and the adaptation of the company to the uncertainty in the environment.

Relational-oriented exchanges stem from the level of interdependence. That is the mutual dependence between supplier and manufacturer. For the reflection of interdependence variable, two concepts are identified which are magnitude and asymmetry $[28,29]$. The magnitude of this interdependence is referred to as the total dependence within the exchange and the asymmetry of dependence at the comparative dependence level.

High magnitude of interdependence impacts the creation of relational structures and processes as the close relationship encourages the employment of non-coercive force, reduces conflict, foments stability and promotes durability [30]. The degree of dependence of a supplier on a manufacturer may also influence relationship behavior. This is because high dependence implies that a valued resource is available from the manufacturer which represents potentially gainful payoffs. To ensure continued supplies in a high dependence situation, one should be expected to cooperate, even if it is non-voluntary in nature. For low 
dependence, the level of relationship may be conditioned by other factors but is likely to be lower since desired payoffs may be perceived to be low and not immediately forthcoming. Drawing upon the previous empirical evidences, industrial applications and new concepts in relationship management, it is posited that higher level of dependence between supplier and manufacturer is hypothesized to be positively related to relational-oriented exchanges. The above arguments lead to:

Hypothesis 1: Higher level of dependence has a significant positive impact on relational-oriented exchanges

\subsection{Trust and Relational -Oriented Exchange}

According to [31], trust, the belief of the reliability of the word of one party and his fulfilment of the obligation, is significantly linked to the firm's inclination for collaboration. In addition, [32] claimed that keeping other things constant, exchange relationships involving trust are able to withstand great stress and present higher adaptability while [33] stated that lack of trust will be damaging to information exchange, to the mutual influence and it will decrease the optimum joint problem solving. This statement is reinforced by [23] stating that following the establishment of trust, the supplier and manufacturer become convinced that joint efforts result in outcomes that go above what each of them could achieve. In conclusion, the literature concerning trust states that successful partnerships should have ingrained high levels of trust.

Building upon this rationale, trust is defined as the inclination to depend on an exchange partner whom one is confident of. It acts as an alternative to a hierarchical control [34] and enables the creation of versatile structures [35] to the extent that it removes the wariness against opportunistic behavior and heightens satisfaction in the relation and continuous expectations [17], and in doing so, cements cooperation, coordination, collaboration and communication [36,37]. Great levels of trust allow organizational members to concentrate on achieving their main goal and save them from having to deal with secondary crises that exist in a low-trust environment. A low trust environment can freeze interactions as it drives the direction of the processes under suspicion, monitoring, or activation of contractual safeguards [38], while trust encourages voluntary and non-obligatory extra efforts between the two parties like any special treatment, and enables the adaptation to future issues and hence, it is considered as a significant high-performance component.

Partnerships between supplier and manufacturer, presenting greater levels of trust, show greater success compared to their counterparts [11] as greater levels of trust pave the way for tighter bonds between individuals and firms. These bonds result in relationship sustenance rather than break up. An indication of partnership efficacy is the prediction of its longer life [24]. Firms who trust their partners to a great extent present higher satisfaction with the partnership and thus, a satisfying partnership arises when mutual expectations of the partnership have been reached [23]. [10]proposed trust-commitment theory to clarify the way trust and commitment lead to successful relational exchanges. Based on the empirical evidences, a social perspective as trust is posited as positively related to relational-oriented exchanges. The above arguments lead to:

Hypothesis 2: Higher level of trust has a significant positive impact on relational-oriented exchanges

\subsection{Communication Behavior and Relational-Oriented Exchange}

Communication processes and the sharing of information are the basis of many organizational functioning aspects $[12,39]$. Two communication behavior aspects addressing the level of information exchange are invaluable to the relationship namely, information sharing, and the level of information quality and participation. These aspects of information sharing (quantity and quality) are needed for the successful development of suppliermanufacturer relationships. Communication's impact on relational sentiments should come out as positive and it cements the channel of distribution and develops an environment characterized by mutual support and participative decision making [12].

Information Quality: The supplier's commitment to the manufacturing may be enhanced following the organization's provision of greater information quality. In the context of interorganizational level; [40] revealed that a strong relation exists between communication quality and two kinds of organizational commitment which are consensus and resource. Information quality was also found to be related to the supplier-manufacturer relationship in a positive way [41]. The expectation is such that following the supplier's perception of the usefulness of information in a timely, clear and thorough manner, his commitment to the business relation will be reinforced.

Information Sharing: Information sharing (both quantity and quality) is considered as the level of critical and proprietary information encapsulating organizational skills and routines and communicated to one's strategic alliance partner $[11,42]$. [43] revealed that almost 30 percent is spent by purchasing managers and their colleagues of their working hours on externally communicating with suppliers as cited in [44]. Communication with varying people from companies encapsulates the use of information exchanged [11], and transforms into the most significant supply chain management skills needed by purchases to carry out oral as well as written communication efficiently $[44,45,46]$. Effective information sharing develops information value for people within and across organizations, and reduces the potential conflict among collaborative supplier-manufacturer relationship [47].

Both manufacturers and suppliers have perceived that information sharing contributes to operating efficiency and mutual benefit between trading partners in cross-national collaboration, thus improving performances [48]. $5 \mathrm{~m}$, information sharing has emerged as a key construct in the arda of strategic suppliermanufacturer relationship, and therefore has been revealed to be a significant predictor of relationship success $[11,44,47,48,49,42,50]$.

Information Participation: Information participation is considered as the level to which partners take part in planning and goal setting in a joint manner [11]. The two information attributes of sharing and participation are linked to the strategic supplier relationship and are significant in the coordination of both parties' activities. For example, the purchasing executive has to be committed to offer superior and correct forecasts of requirements to suppliers to facilitate better planning of available capacity $[51,52,53,54]$. This implies that relational oriented exchanges are linked with greater levels of information participation. The above arguments lead to:

Hypothesis 3: High level of communication behavior has a significant positive impact on relational-oriented exchanges

\subsection{Relational-Oriented Exchange and Outsourcing Success}

Based on the literature, firm performance is impacted by its strength to integrate, develop and reconfigure resources in a process known as dynamic capabilities [55]. More specifically, dynamic capabilities clarify why firms in one industry perform in different ways. For instance, [56] posit that dynamic capabilities are ingrained in firms and comprise of a set of specific and clear strategic and organizational processes while [57] revealed that 
firms characterized by a dedicated capability in managing interfirm relationships produced greater market value compared to their lacking of capability counterparts. In other words, companies systematically investing in the development of the management of supplier-manufacturer relationship display consistent performance compared to those who forego such investments. As such, it can be stated that investments in the development of relational-oriented exchanges minimizes both coordination and integration costs and enhances the synergistic advantages existing through strategic outsourcing.

Many researchers have highlighted the increasing trend of outsourcing see e.g. $[58,59]$. Through the outsourcing of activities to experienced suppliers, companies are able to concentrate on their core products and activities [60]. This specialization in core activities allows the minimization of the capital base and facilitates enhanced return on invested capital [61] and opens the firm to the possibilities of taking advantage of economies of scale. Nevertheless, outsourcing would entail placing important activities external to the firm [62]. Therefore, manufacturers and suppliers are required to cooperate through the relational exchange the co-ordination of these activities in an efficient manner [63].

In short, relational-oriented exchanges enable firms to produce greater value $[64,65]$ and at the same time help develop additional benefits for firms over time [66]. Outsourcing firms provide the chance to benefit from the cost advantages in comparison to their vertically integrated counterparts $[67,68,70,71]$. Outsourcing leads to decreased manufacturing and minimal investment in plant and equipment [67]. Moreover, the decreased investment in manufacturing capacity also decreases the fixed costs and results in an even lower break-even point. The improvement in short-run cost supports the decision to outsource making it an attractive technique for firms to improve their financial performance particularly in the short run. The above arguments lead to:

Hypothesis 4: Relational-oriented exchanges have a significant positive impact on outsourcing success in terms of financial performance.

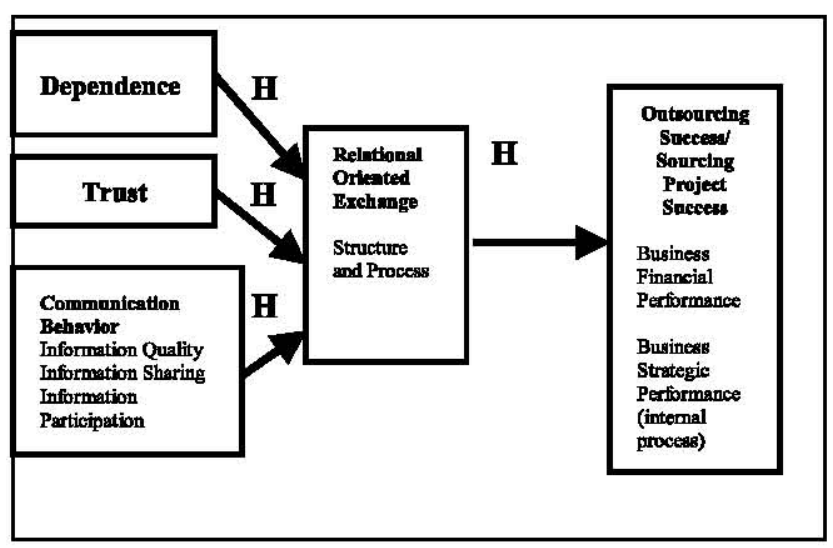

Figure 1 Research Framework

\section{B.0 RESEARCH METHODOLOGY}

A quantitative research approach was considered appropriate for this study. Questionnaire was used to collect data for this study through a postal survey. In order to achieve the stated objective of the study, the Malaysian Electrical and Electronic industries were selected as the population of the study. The listing of the industries was selected from the directory of the Federation of
Malaysian Manufacturer [72]. The selection of the corresponding industry was based on the International Standard Industrial Classification Code (ISIC). The firms involved in this study are those with the numbers of employees greater than 100 . This followed the decision made by [73] who suggested that in outsourcing management studies, one should only consider companies that have more than 100 employees which are organizations that are large enough to participate actively in outsourcing management practices. Based on the selection criteria, 865 companies that are listed as manufacturers of electrical and electronic companies were chosen to participate in this study. Respondents' quality is a crucial factor and the chosen respondents are expected to be the most knowledgeable regarding the operation and management of the organization outsourcing. Hence, the respondents are the managers in purchasing, materials planning, general managers or directors.

The questionnaire consists of four (4) sections: general information about the organization and respondents' profile, factors as the antecedents of supplier-manufacturer relationship, the relational orientation of the exchange and the outsourcing performance. The general information collects information on the profiles of the organization related to company ownership, the type of manufacturing industry, the type of products produced, the respondent's working experience with multinational companies, the respondent's involvement in outsourcing, the respondent's position in the company, the organization's operation years in Malaysia and the organizations' size according to the number of employees. The objective of this section is to understand the general profile of the organization.

Section two (2) of the questionnaire contained 37 items that probe the antecedents of supplier-manufacturer relationships related to the economy factor (dependence), social factor (trust) and communication behavior (information quality, information sharing and information participation). The objective of this section is to identify the factors as antecedents of suppliermanufacturer relationships. The measurement instruments for dependence are adapted from [17]; trust from [10]; information quality, information sharing and information participation from [11]. The items were measured on a 7-points Likert scale which investigates the extent of level ranging from 7 for "Strongly Agree" to 1 for "Strongly Disagree".

The third section investigates the relational-oriented exchange which has been categorized as structure and process aspects: expectation of continuity, team-consciousness, cooperation and communication which consisted of 8 items. The measurement instruments for structure and process are adapted from [74]. The measurement is gauged through a 7-points Likert scale which measures the extent of level ranging from 7 for "Strongly Agree" to 1 for "Strongly Disagree".

The fourth section contains two sub-constructs that are customers' intangible benefits (14 items) and tangible benefits (3 items). This section is designed to understand the benefits of outsourcing success acquired by the organization. The questions are modified from past studies by [69] and [13] to be structurally short and precise. In addition, the sequencing of this section is done in a logical manner, starting from an organization's outsourcing success related to cost before attempting to find out more about the organization's outsourcing success related to strategic performance/internal process performance. The measurement is measured o D points Likert scale ranging from 7 for "Strongly Agree" to $1 \mathrm{for}$ Strongly Disagree". Measurement of environmental factors is newly developed and crossed referenced to available literature reviews.

Upon the completion of the instrument development in this study, the developed instrument was subjected to a pre-test (content validity and reliability test). The result of the validity and 
the reliability test revealed that the items of developed instruments measured the content intended by the researcher while the reliability test of the collected data reveals that the instrument is internally consistent (Cronbach's alpha greater than 0.7). Subsequently, the main data collected was analyzed using the Statistical Package for Social Science (SPSS) version 19.

\subsection{FINDINGS}

A total of 865 postal surveys were sent out in two waves to the respondents. The total responses received were 224. Six (6) of the responses were rejected due to incomplete information in the responses. Hence, the final number of completed and usable responses is 218 . The response rate is based on the following assumption:

\begin{tabular}{|c|c|c|c|c|c|c|c|}
\hline Model & $\begin{array}{c}\text { Un- } \\
\text { Std } \\
\text { Beta }\end{array}$ & $\begin{array}{l}\text { Std. } \\
\text { Err } \\
\text { or }\end{array}$ & $\begin{array}{l}\text { Std } \\
\dot{B e t} \\
\text { a }\end{array}$ & $\mathbf{t}$ & Sig. & $\begin{array}{c}\text { Collinea } \\
\text { Statist } \\
\text { Toleran } \\
\text { ce }\end{array}$ & $\begin{array}{l}\text { ty } \\
\text { VI } \\
\text { F }\end{array}$ \\
\hline (Constant) & .497 & .291 & & $\begin{array}{l}1.7 \\
10\end{array}$ & .089 & & \\
\hline $\begin{array}{l}\text { Dependenc } \\
\mathrm{e}\end{array}$ & .388 & .060 & $\begin{array}{c}.36 \\
5\end{array}$ & $\begin{array}{l}6.4 \\
56\end{array}$ & $\begin{array}{l}.000 \\
* * *\end{array}$ & .861 & $\begin{array}{l}1.1 \\
61\end{array}$ \\
\hline Trust & .001 & .074 & $\begin{array}{c}.00 \\
1\end{array}$ & $\begin{array}{c}.01 \\
8\end{array}$ & .986 & .541 & $\begin{array}{l}1.8 \\
47\end{array}$ \\
\hline $\begin{array}{l}\text { Communic } \\
\text { ation } \\
\text { behavior }\end{array}$ & .475 & .081 & $\begin{array}{c}.42 \\
8\end{array}$ & $\begin{array}{l}5.8 \\
61\end{array}$ & $\begin{array}{l}.000 \\
* * *\end{array}$ & .516 & $\begin{array}{l}1.9 \\
37\end{array}$ \\
\hline
\end{tabular}

Response Rate $=\underline{T o t a l}$ response received - Rejected responses Total response sent

Based on this assumption, the effective response rate is 25.2 per cent [(224 - 6)/865]. The first wave yielded 147 responses and the second wave yielded 71 responses. Such response rate is within the acceptable range as previous studies from Malaysian manufacturing researches yielded a similar range between 18-26 per cent $[75,76,77]$.

The findings of this study reveal that 35.7 per cent of the responding organizations are owned by Malaysians whereas the remaining 63.8 percent are owned by foreigners. From the foreign ownership, US and European owned companies constituted 59.7 per cent and only about 40 per cent are owned by Asians (Japanese, Korean or Singaporean) implying that local electrical and electronic industry heavily relies on foreign investors. The electrical sector constituted 51.4 per cent whereas the electronic sector constituted 48.6 per cent. The response rate distribution is balanced between both sectors. 79 per cent of the organizations have more than 150 employees. Only 20 per cent of the responding organizations have between 50 to 150 employees. This reflected the earlier recommendation that organizations need to have more than 100 employees to be involved in outsourcing programs [73]. 100 per cent of the surveyed organizations acknowledged that they have been involved in outsourcing management. The statistic provided an assurance that the organizations surveyed have engaged in outsourcing activities and are valid for future statistical analysis. The result further shows that only 28.6 per cent of the target respondents have work experience in outsourcing for less than 5 years. About 71.4 per cent of the respondents have work experience of more than 5 years and above. This adds credibility to the respondents' knowledge on outsourcing activities. In addition, majority of the respondents ( 74.3 per cent) has a tertiary education. Only 25.7 per cent of the respondents have lower than tertiary education. With this, targeted respondents should not have a problem in understanding the contents of the questionnaire.

\subsection{Result of Hypotheses Testing}

Multiple regression analysis was performed in the determination of the association among the variables. Consequently, the result of the regression analysis identifies the most contributory variables among the set of antecedents of relational exchanges that best predict the relational-oriented exchange factor (expectation of continuity, team-consciousness, cooperation and communication). The result showed in the Table 2 demonstrate that the regression equation with predictors was significant, $\mathrm{R}=$ $.657, \mathrm{R}^{2}=.432, \mathrm{R}^{2} \mathrm{adj}=.424, \mathrm{~F}(3,210)=52.268, \mathrm{p}<.001$. In other words, the multiple correlations between the predictor and the dependent variable were .657 ; the predictor accounted for 43.2 per cent of the variance in the relational-oriented exchange. The generalizability of this model in another population was .424. The value of $\mathrm{R}^{2}$ dropped to only .008 (about 1 per cent) in the adjusted $\mathrm{R}^{2} \mathrm{adj}$, which indicates that the cross validity of this model was fine.

The significant F-test revealed that the relationship between the dependence variable (Relational-oriented Exchange) and independent variables (Dependence, Trust and communication behavior) was linear and the model significantly predicted the dependent variable. The F-test $(3,210)=52.268, \mathrm{p}<0.001)$ indicates on overall significant prediction in the independent variables to the dependent variables, but lack of information about the importance of each independent variable. Table 2 shows the individual contributor of each predictor with a regression equation. Among the three predictors, communication behavior ( $\beta$ $=.428, \mathrm{t}=5.861, \mathrm{p}=.000)$ had the highest standardized beta coefficient, which indicates that communication behavior, was the most important variable in predicting relational-oriented exchanges.

Table 2 Multiple Regression Result between Relationships Motivations (RM) and Relational-oriented Exchange

\begin{tabular}{ccccccc}
\hline $\mathbf{R}$ & $\mathbf{R}^{2}$ & $\begin{array}{c}\text { Adjusted } \\
\mathbf{R}^{\mathbf{2}}\end{array}$ & $\begin{array}{c}\text { Error of } \\
\text { the } \\
\text { Estimate }\end{array}$ & $\mathbf{F}$ & Sig. & $\begin{array}{c}\text { Durbin- } \\
\text { Watson }\end{array}$ \\
\hline .657 & .432 & .424 & .92582 & 52.268 & .000 & 1.658 \\
\hline
\end{tabular}

a. Dependent Variable: Relational-oriented exchange

The other important predictor in descending order was dependence $(\beta=.365, \mathrm{t}=6.456, \mathrm{p}=.000)$. However, trust $(\beta=$ $0.001, \mathrm{t}=.018, \mathrm{p}=.986)$ was not significantly related to relational-oriented exchanges.

The result of the test between the relational-oriented exchange factor and outsourcing success revealed that the regression equation with predictor was significant, $\mathrm{R}=.638, \mathrm{R}^{2}=$ $.406, \mathrm{R}^{2} \mathrm{adj}=.404, \mathrm{~F}(1,210)=142.454, \mathrm{p}<.001$. In other words, the multiple correlation coefficients between the dependent variable were .638 ; the predictor accounted for 40.6 per cent of the variance in the outsourcing success. The generalizability of this model in other population was .404 as shown in Table 3. 
Table 3 Multiple Regression Result between Relational-oriented Exchange Factor and Outsourcing Success

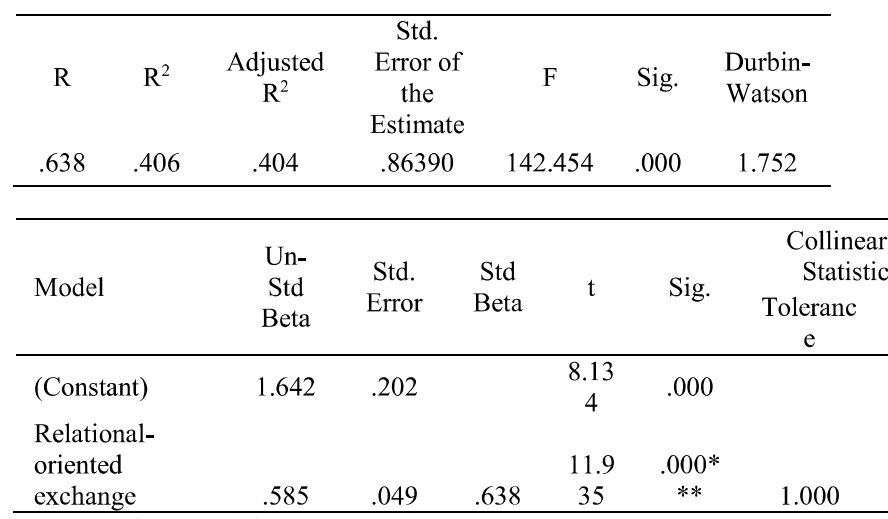

a. Dependent Variable: outsourcing success

The value of $\mathrm{R}^{2}$ dropped to only 0.002 (about 0.2 per cent) in the adjusted $\mathrm{R}^{2} \mathrm{adj}$, which indicates that the cross validity of this model was fine. The significant $\mathrm{F}$-test revealed that the relationship between dependent variable and independent variables was linear and the model significantly predicted the dependent variable. The $\mathrm{F}(1,210)=142.454, \mathrm{p}<.001$, indicates an overall significant prediction in the independent variables which is relational-oriented exchange factor $(\beta=.638, \mathrm{t}=11.935$, $\mathrm{p}=0.000)$ as an important variable in predicting the outsourcing success.

The summary of the test of hypotheses in this study is presented in Table 4.

Table 4 Summary of Hypotheses Testing on the effect of the antecedents of relational oriented exchange on the Relational-oriented Exchange

\begin{tabular}{|c|c|c|}
\hline Hypotheses & Statements of Hypotheses & Remarks \\
\hline $\mathrm{H}_{\mathrm{A}}: 1$ & $\begin{array}{l}\text { Higher level of dependence has a } \\
\text { significant positive impact on } \\
\text { relational-oriented exchanges }\end{array}$ & $\begin{array}{l}\text { Supported } \\
\mathrm{H}_{\mathrm{A}} \text { : } \\
\text { hypotheses }\end{array}$ \\
\hline $\mathrm{H}_{\mathrm{A}}: 2$ & $\begin{array}{l}\text { Higher level of trust has a significant } \\
\text { positive impact on relational- } \\
\text { oriented exchanges }\end{array}$ & $\begin{array}{l}\text { Not } \\
\text { supported } \\
\mathrm{H}_{\Lambda} \text { : } \\
\text { hypotheses }\end{array}$ \\
\hline $\mathrm{H}_{\mathrm{A}}: 3$ & $\begin{array}{l}\text { High level communication behavior } \\
\text { has a significant positive impact on } \\
\text { relational-oriented exchanges }\end{array}$ & $\begin{array}{l}\text { Supported } \\
\mathrm{H}_{\mathrm{A}} \text { : } \\
\text { hypotheses }\end{array}$ \\
\hline $\mathrm{H}_{\mathrm{A}}: 4$ & $\begin{array}{l}\text { Relational-oriented exchange factor } \\
\text { has a significant positive impact on } \\
\text { outsourcing success }\end{array}$ & $\begin{array}{l}\text { Supported } \\
\mathrm{H}_{\mathrm{A}}: \\
\text { Hypotheses }\end{array}$ \\
\hline
\end{tabular}

\subsection{DISCUSSION AND IMPLICATION}

Multiple regression analysis was conducted to examine the highest contributor of explanatory variables among the RM factors that best predict the relational-oriented exchange variable. The results indicate that dependent, trust and communication behavior jointly explained 43 per cent of the variance of the relational-oriented exchanges. Two predictor variables, dependence and communication behavior were found to be statistically related to relational-oriented exchanges. Communication behavior was the strongest contributor predictor that explains the variance of relational-oriented exchange, followed by dependence.
The mixed results between the individual dimensions of the RM factors and relational-oriented exchange variable of this study suggest that the first and third hypotheses were supported while the second hypothesis was not supported. The present study revealed statistical significant results between the relationship of $\mathrm{RM}$ factors and relational-oriented exchanges of electrical and electronic manufacturing companies which are consistent with the findings of prior studies $[78,79,80]$, whereby it was also revealed that the interaction of economic and social factors are Collinearify terminants in the industrial supplier-manufacturer relationship. Although the results of the present study indicate mixed results, theFoverall finding suggests that RM factors are significant and they jointly explain the variance of the relational-oriented exchange variable. The evidence from this study suggests that high levels of RM factors are related to high level of strategic relationship. However, the individual dimensions of RM factors that contribute strongly to the relational-oriented exchange need to be taken into consideration by organizations that wish to strengthen the relationship.

Furthermore, the non-significant results concerning the relationship between RM variable and supplier-manufacturer strategic relationship in the electrical and electronic manufacturing companies are in line with some studies $[17,81]$. According to [81], the lack of trust may still lead to continuous relationship while supplier viewpoints reveal that the trust perception is not a relevant determinant of long-term orientation. Despite the unexpected result, it implies that suppliers focus on the objective evidence of dependability as opposed to their channel partner's motives.

Stated differently, the findings imply that the variance in the relational-oriented exchange is expounded by specific RM factors. Hence, the findings imply that the relational-oriented exchange could be enhanced through RM. Specifically, this study found that: (1) the relational orientation of exchange may be improved through a high level of dependency; (2) the relational orientation of exchange may be improved through a higher level of communication behavior.

Overall, the results of the correlation analysis revealed that dimension between RO and outsourcing success was significant. The results of the correlation analysis suggest that high levels of RO attributes are related to high level of outsourcing success. This study hypothesized that RO has a significant positive relationship with outsourcing success (hypothesis 4). The variance in the outsourcing success is explained by the relational-oriented exchange. The present study particularly revealed that the outsourcing performance in light of implementation factors the company carries out for the achievement of its objectives, goals and expectations may be improved through supplier-manufacturer strategic relationship. The evidence from this study suggests that a relational-oriented exchange is important to organizations. Indeed, high level of relational-oriented exchanges relates to a high level of outsourcing success.

\subsection{CONCLUSION AND FUTURE-WORK}

The results indicate that the relational-oriented exchange is positively related to the outsourcing success. Stated differently, the achievement level in outsourcing performance may hinge on the degree of relational-oriented exchanges. A higher degree of relational-oriented exchanges may lead to higher level outsourcing success. For the assessment of the relational orientation of exchange in the form of strategic relations, it is necessary to look beyond just specific transactions but to related components and relationships that surround them in light of relational norms of the partner in the exchange. The study stands 
as a basis on which further empirical investigation can be done on other subsectors of Malaysia manufacturing sector.

\section{References}

[1] MIDA. 2010a.Malaysian Industrial Development Authority report, ICT \& Electrical Industries Division.

[2] M. Fichman, and P. Goodman. 1996. Customer-supplier ties in interorganizational relations'. Research in Organizational Behavior. 8: 329.

[3] L.W. Stern, and T. Reve. 1980. Distribution channels as political economies: A framework for comparative analysis. Journal of Marketing. 44(3):.52-64.

[4] I.R. Macneil. 1980.The New Social Contract : An Inquiry Into Modern Contractual Relations. New Haven: Yale University Press.

[5] C.C. Izquierdo, and J.G. Cillan. 2004. The interaction of dependence and trust in long-term industrial relationships'. European Journal of Marketing. 38(8): 974-994.

[6] C.J.Lambe, R.E. Spekman, and S.D. Hunt. 2000. Interimistic relational exchanges: conceptualization and propositional development.Journal of the Academy of Marketing Science.28(2): 212-225.

[7] C. Oliver. 1990. Determinants of interorganizational relationships: integration and future directions. Academy of Management Review. 15(2): 241-265.

[8] R.W. Palmatier, R.P. Dant, and D. Grewal. 2007. A Comparative Longitudinal Analysis of Theoretical Perspectives of Interorganizational Relationship Performance. Journal of Marketing. 71: 172-194.

[9] G. Frazier. 1983. Interorganizational exchange behaviour in marketing channels: a broadened perspective'. Journal of Marketing. 47:.68-78.

[10] R.M. Morgan, and S.D. Hunt. 1994. The commitment-trust theory of relationship marketing. Journal of Marketing. 58(3): 20

[11] J. Mohr, and R. Spekman. 1994. Characteristics of partnership success: partnership attributes, communication behavior, and conflict resolution techniques.Strategic Management Journal. 15: 135-152.

[12] J. Mohr, and J.R. Nevin. 1990. Communication strategies in marketing channels: A theoretical perspective. Journal of Marketing. 54(4): 36

[13] D. Elmuti. 2003. The Perceived Impact of Outsourcing on Organizational Performance.Mid-American Journal of Business. 18(2): 33-37.

[14] K.W. Khong. 2005. The perceived impact of successful outsourcing on customer service management. Supply Chain Management: An International Journal. 10(5):.402-411.

[15] J.R. Kroes, and S. Ghosh. 2010. Outsourcing congruence with competitive priorities: Impact on supply chain and firm performance.Journal of Operations Management. 28(2):.124-143.

[16] J.L. Perry, T.A.Engbers, and S.Y. Jun. 2009. Back to the Future? Performance-Related Pay, Empirical Research, and the Perils of Persistence.Public Administration Review. 69(1): 39-51.

[17] S. Ganesan. 1994. Determinants of long-term orientation in buyer-seller relationships. Journal of Marketing. 58(April): 1-19.

[18] R. Daft, and R. Lengel. 1986. Organizational information requirements, media richness, and structural design.Management Science. 3(5): 554571.

[19] G. Huber, and R. Daft. 1987. The information environment of organizations. In F. Jablin et al. (ed.). Handbook of Organizational Coommunication.

[20] F. Jablin, L. Putnam, K. Roberts, and L. Porter. 1987. Handbook of Organizational Communication. Newbury Park, CA: Sage Publications.

[21] C. Stohl, and W.C. Redding. 1987. Messages and message exchange processes. In F. Jablin et al. (eds). Handbook of Organizational Communication: An Interdisciplinary Perspective. Sage Publications, Newbury Park, CA. 451-502.

[22] E. Anderson, L.Lodish, and B. Weitz. 1987. Resource allocation behavior in conventional channels. Journal of Marketing Research. 24: 85-97.

[23] J. Anderson, and J.A. Narus. 1990. A model of distributor firm and manufacturer firm working partnerships. Journal of Marketing. 54(January): 42-58.

[24] J. Anderson,H. Hakansson, and J. Johanson. 1994. Dyadic Business Relationships within a Business Network.Journal of Marketing. 58(4): 115 .

[25] K. Cook.1977. Exchange and power in networks of interorganizational relations. The Sociological Quarterly. 18: 62-82.

[26] S. Levine, and P. White. 1962. Exchange as a conceptual framework for the study of interorganizational relations. Administrative Science Quarterly. 5: 583-601.

[27] T. Cummings. 1984. Transorganizational development. Research in Organizational Behavior. 6: 367-422.
[28] L. Buchanan. 1992. Vertical trade relationships: The role of dependence and. Journal of Marketing Research. 29(1): 65.

[29] G. Gundlach, and E. Cadotte. 1994. Exchange interdependence and interfrm interaction: research in a simulated channel setting.Journal of Marketing Research. 31(November): 516-532.

[30] I.C. Carmen, and C.G. Jesus.2004. The interaction of dependence and trust in long-term industrial relationships. European Journal of Marketing, 38(8): 974-994.

[31] D.G. Pruitt.1981.Negotiation Behavior. New York: Academic Press.

[32] O.E. Williamson. 1985. The Economic Institutions of Capitalism. New York, NY: The Free Press.

[33] D. Zand. 1972. Trust and managerial problem solving. Administrative Science Quarterly. 17: 229-239

[34] A. Rindfleisch, and J.B. Heide. 1997. Transaction cost analysis: past, present and future applications. Journal of Marketing. 61(October): 3054.

[35] A. Zaheer, and N. Venkatraman.1995. Relational Governance as an Interorganizational Strategy: An Empirical Test of the Role of Trust in Economic Exchange. Strategic Management Journal. 16(June): 373-392.

[36] A. Joshi, and R.L Wand Stump. 1999. The contingent effect of specific asset investment on joint action in manufacturer supplier relationships: an empirical test of the moderating role of reciprocal asset investments, uncertainty and trust. Journal of the Academy of Marketing Science 27(3): 291-305.

[37] J.B Smith, and D. Barclay. 1997. The effects of organizational differences and trust on the effectiveness of selling partner relationships. Journal of Marketing. 61: 3-21.

[38] J.D.Lewis, and A. Weigert. 1985. Trust as Social Reality. Social Forces. 63(4): 967-985.

[39] J. Kapp, and Barnett, G. 1983. Predicting organizational effectiveness from communication activities: A multiple indicator model. Human Communication Research. 9: 239-254.

[40] A. Menon, S.G.Bharadwaj, P.T. Adidam, and S.W. Edison. 1999. Antecedents and Consequences of Marketing Strategy Making: A Model and a Test. Journal of Marketing. 63(2): 18-40.

[41] P.K.. Humphreys, W.L. Li, and L.Y. Chan. 2004. The Impact of Supplier Development on Buyer-Supplier Performance. Omega. 32(2): 131-143.

[42] M.J. Robson, D. Skarmeas, and S.Spyropoulou. 2006. Behavioral attributes and performance in international strategic alliances: Review and future directions. International Marketing Review. 23(6): 585-609.

[43] S. Davis, R. Large,R. Halstead-Nussloch, and Z. Kovacs. 2003. Internet usage in purchasing: comparison of US and European practice. Saarbrücken Working Paper Series in Logistics and Supply Management'. No. 1, HTW Saarland, Saarbrücken.

[44] R. O. Large. 2005a. Communication capability and attitudes toward external communication of purchasing managers in Germany. International Journal of Physical Distribution \& Logistics Management. 35(6): 426-444.

[45] B.Gammelgaard, and P.D. Larson. 2001. Logistics skills and competencies for supply chain management. Journal of Business Logistics. 22(2): 27-50.

[46] L.C.Giunipero, and D.H. Pearcy. 2000. World-class purchasing skills: an empirical investigation. The Journal of Supply Chain Management. 36(4): 4-13

[47] S. Kauser, and V. Shaw. 2004. The influence of behavioural and organisational characteristics on the success of international strategic alliances. International Marketing Review. 27(1): 17-52.

[48] M.S. Cheung, and M.B.Myers. 2008. Managing knowledge sharing networks in global supply chains'. International Journal of Management and Decision Making. 9(6): 581-599.

[49] R. Monczka, K. Petersen, R. Handfield, and G. Ragatz. 1998. Success factors in strategic supplier alliances: The buying company perspective. Decision Sciences. 29(3): 553-577.

[50] K.E. Voss, J.L. Johnson,J.B. Cullen,T. Sakano, and H. Takenouchi. 2006. Relational exchange in US-Japanese marketing strategic alliances. International Marketing Review. 23(6): 610-635.

[51] S. Chapman, and P. Carter. 1990. Supplier/customer inventory relationships under just-in-time. Decision Sciences. 21(1): 35-51.

[52] R.B. Handfield.1993. A resource dependence perspective of just-in-time purchasing.Journal of Operations Management. 11(3): 289-311.

[53] J. Im, and S. Lee. 1989. Implementation of just-in-time systems in U.S. manufacturing firms.International Journal of Operations and Production Management. 13(1): 5-14.

[54] A.Raturi, J. Meredith, D. McCutcheon, and J. Camm. 1990. Coping with the build-to-forecast environment. Journal of Operations Management. 9(2): 230-249.

[55] D.J.Teece,G. Pisano, and A. Shuen. 1997. Dynamic capabilities and strategicmanagement.StrategicManagement Journal. 8(7): 509-533. 
[56] C. Helfat, M.A.E and Peteraf. 2003. The dynamic resource-based view: capability lifecycles.Strategic Management Journal. 24(10): 997-1010.

[57] P. Kale,J.H. Dyer, and H. Singh. 2002. Alliance capability, stock market response, and long-term alliance success: the role of the alliance function. Strategic Management Journal. 23(8): 747-767.

[58] R.T. McIvor, P.K.Humphreys, and W.E. McAleer. 1998. European car makers and their suppliers: changes at the interface. European Business Review. 98(2): 87-99.

[59] Mercer, G. 1995. Modular supply in the 1990s - the keys to success', Europe's Automotive Components Business, 2nd quarter: 112-135.

[60] R. Venkatesan. 1992. Sourcing: to make or not to make. Harvard Business Review. 98-107.

[61] J.B. Quinn, and F.G. Hilmer. 1994. Strategic outsourcing. Sloan Management Review. 43-55.

[62] G.B. Richardson. 1972. The organization of industry.The Economic Journal. 883-896.

[63] A. Dubois. 1994.Organizing Industrial Activities - An Analytical Framework. Doctoral dissertation, Chalmers University of Technology, Gothenburg.

[64] J.T. Mahoney, and J.R. Pandian. 1992. The resource-based view within the conversation of strategic management. Strategic Management Journal. 13(5): 363-380.

[65] R. Makadok. 2001. Toward a synthesis of the resource-based and dynamic-capability views of rent creation. Strategic Management Journal. 22(5): 387-401.

[66] R.P. Rumelt. 1984. Towards a strategic theory of the firm rm. In Lamb, R.B. (Ed.), Competitive Strategic Management. Englewood Cliffs, NJ: Prentice-Hall. 556-570.

[67] R. Bettis,S. Bradley, and G. Hamel. 1992. Outsourcing and industrial decline.Academy of Management Executive. 6(1): 7-22.

[68] M. Kotabe. 1989. Hollowing-out of U.S. multinationals and their global competitiveness: An intrafirm perspective. Journal of Business Research. 19: $1-15$.

[69] M. Kotabe. 1998. Efficiency vs. effectiveness orientation of global sourcing strategy: A comparison of U.S. and Japanese multinational companies.Academy of Management Executiv. 12(4): 108-118.
[70] D. Lei, and M. Hitt. 1995. Strategic restructuring and outsourcing: The effect of mergers and acquisitions and LBOs on building firm skills and capabilities. Journal of Management. 21(5): 835-859.

[71] J.B. Quinn. 1992. Intelligent Enterprise: A Knowledge And Service Based Paradigm For Industry. New York: Free Press.

[72] FMM. 2010. Federation of Malaysian Manufacturers Directory, Malaysian Industries. Kuala Lumpur: FMM (38th. edition).

[73] L. Ying. 2006. Supply Chain Flexibility: Antecedents Driving Force Impacts on Performance, Doctoral Dissertation. University of Toledo, Toledo, $\mathrm{OH}$.

[74] T.G. Noordewier, G. John,J.R. Nevin. 1990. Performance Outcomes of Purchasing Arrangements.Journal of Marketing. 54(4): 80-93.

[75] P. Rajagopal. 2006.Determinants Of Effective Supply Chain Partnering In The Context Of Electrical And Electronics Firms In Malaysia, Doctoral Dissertation. Universiti Sains Malaysia, Penang.

[76] L.S. Thi. 2006.Electronic Commerce Adoption Among Manufacturing SMEs in Malaysia, Dissertation. University Utara Malaysia.

[77] P.L. Yean,S. Zailani, and K.L. Soh. 2006. Understanding factors for benchmarking adoption: New evidence from Malaysia. Benchmarking International Journal. 13(5): 548-565.

[78] K.D. Bradford,J.M. Crant, and J.M. Phillips. 2009. How suppliers effect trust with their customers: the role of selesperson job satisfaction and perceived customer importantce. Journal of Marketing Theory and Practice. 17(4): 383-395.

[79] J.R. Brown, J.L. Crosno, and C.S. Dev. 2009. The effects of transactionspecific investments in marketing channels: the moderating role of relational normas. Journal of Marketing Theory and Practice. 17(4): 317-334.

[80] Y.M. .Everdingen,L.M. Sloot, E.V.Nierop, and P.C. Verhoef.2011. Towards a Further Understanding of the Antecedents of Retailer New Product Adoption. Journal of Retailing. 87(4): 579.

[81] S.S. Andaleeb. 1995. Dependence relations and the moderating role of trust implications for behavioral intentions in marketing channel. International Journal of Research in Marketing. 12: 157-172. 